\title{
The effect of herbal salt as a natural antioxidant in preserving fish during freezing storage
}

\author{
Giselda Macena LIRA ${ }^{1 *}$ (D), Ana Maria Queijeiro LOPEZ ${ }^{2}$, Gabriela Marques de Farias NANES ${ }^{1}$, \\ Fernanda Geny Calheiros SILVA ${ }^{1}$, Ticiano Gomes do NASCIMENTO ${ }^{3}$
}

\begin{abstract}
The changes in chemical composition, chlorides, phenols and fatty acid profile of roasted or not Dolphinfish (Coryphaena hippurus Linnaeus, 1758) samples, after using or herbal salt or common iodized salt $(\mathrm{NaCl})$, during storage under freezing, were evaluated. The ash and chloride contents were significantly higher $(\mathrm{p}<0.05)$ in samples of the roasted fish previously treated with salt, compared to those treated with herbal salt. Oregano herb had a higher content of phenolic compounds and a significant difference ( $\mathrm{p}<0.05$ ), compared to rosemary and basil herbs. At time "zero", or after 45 and 90 days of storage under freezing, the fatty acid content of the samples in natura, showed no significant difference $(p>0.05)$, when compared to the roasted and pre-treated with herbal salt. However, statistically lower values were detected $(p>0.05)$ in roasted samples pre-treated with salt, showing a positive correlation between phenolic compounds and the antioxidant activity exerted by herbs, in relation to the profile of fatty acids during storage under freezing, preserving nutritional quality. These results contributed to show the good functionality of herbal salt, in addition to encouraging healthy eating habits, by reducing common salt consumption.
\end{abstract}

Keywords: fish; spices; fatty acids; phenols; natural antioxidant; functional food.

Practical Application: As natural antioxidants are increasingly being studied due to their influence on health, this research investigated the antioxidant ability of herbal salt on the preservation of Dolphinfish, a food susceptible to suffer lipid oxidation during storage under freezing. The results were positive in comparison to normal iodized salt, preserving the lipid profile of the fish, avoiding losses in nutritional quality. This encourage the applicability of herbal salt, stimulating the consumption of natural antioxidants, in addition to reducing the consumption of salt, through use.

\section{Introduction}

Herbal salt consists of a mixture of refined table salt with dehydrated herbs, such as oregano (Origanum vulgaris L.), rosemary (Rosmarinus officinalis L.), basil (Ocimum basilicum L.) and laurel (Laurus nobilis L.). It is known that hypertensive patients have difficulty adhering to a sodium-restricted diet (Alencar et al., 2011), however, aromatic herbs, used as condiments, contribute to assist in the acceptance of this type of diet, as well as stimulate the healthy population to reduce and/or care for salt consumption, as a preventive issue. Can be used in any preparation, in total or partial replacement of table salt, in the form of herbal salt (Ghawi et al., 2014).

The spices contained in the herbal salt, in addition to highlighting the sensory characteristics of foods, avoiding monotony of the table, also may give to the consumer health benefits, as they are referred to as nutraceutical foods, with antioxidant and anti-inflammatory properties, mainly due to the activity of phenolic compounds (Elosta et al., 2012). This activities can prevent and/or treat cardiovascular diseases, reducing the inflammatory and oxidative process (Moraes \& Colla, 2006).

Salt, in turn, as a source of sodium, should not be extracted entirely from the diet, since it is important for the control of cellular fluids. Thus, attention should be focused on its reduction instead of total elimination in the diet (International Life Sciences Institute, 2009).

On the other hand, fish is seen as a marker of healthy eating patterns when eaten regularly. Important protein source, of high biological value, for having all the essential amino acids (Food and Agricultural Organization of the United Nations, 2016), rich in vitamins, mineral salts (Sartori \& Amâncio, 2012) and one of the best sources of polyunsaturated fatty acids of the n- series 3, eicosapentaenoic (EPA) and docosahexaenoic (DHA) (Merdzhanova et al., 2012). The benefits of consuming n-3 involve combating and preventing cardiovascular disease, reducing its morbidity and mortality (Bocchi et al., 2012); assistance in the treatment of diabetes (Farsi et al., 2014); strengthening of the immune response (Braga \& Barleta, 2007); preventing and treating neurological diseases (Zemdegs et al., 2009), such as Alzheimer's (Raposo, 2010); treating asthma of children in development and some cancers (Garófolo \& Petrilli, 2006). Due to the health benefits of fish consumption, Verdi et al. (2020), for example, carried out studies incorporating different concentrations of a dehydrated mixture of salmon and tilapia 
in the pizza dough, a very popular food among teenagers and young people. According to these authors, there was no difference between the pizzas for the sensory attributes analyzed after including up to $20 \%$ of the dehydrated mixture in the preparation of the dough, but this was effective in reducing saturated fatty acids and adding proteins, minerals and polyunsaturated fatty acids, maintaining good sensory quality.

However, the composition of these nutrients varies with cooking, which can change the chemical characteristics of the in natura food, with loss of water, which promotes the concentration of nutrients, incorporation of substances from the cooking medium (oil, water, spices) and losses to this medium (Badiani et al., 2002; García-Arias et al., 2003; Saldanha \& Bragagnolo, 2010; Ansorena et al., 2013). Associated with heat, salt becomes a pro-oxidant of fats (Pardi et al., 2001). In fish, this degradation comes mainly from the oxidation of polyunsaturated fatty acids (Cornejo et al., 1999).

Freezing is one of the main storage methods for conserving fish, however, frozen storage for a long time can partly impair the nutritional quality of the fish if there is oxidation of fatty acids. Biochemical interactions, in prolonged frozen storage, may occur between fish muscle proteins and fatty acids (Oetterer et al., 2012). In the search for adequate fish storage, Truonghuynh et al. (2020) evaluated the feasibility of storing large yellow croaker (Pseudosciaena crocea), the main coastal economic fish in China, using cryogenic freezing at different temperatures and freezing by forced convection, and it was seen that forced convection freezing had significantly higher values for drip loss and relative moisture loss when compared to cryogenic freezing, while water holding capacity decreased markedly in both methods. Cryogenic freezing at -60 and $-80{ }^{\circ} \mathrm{C}$ had the highest yellowness values during storage; but the highest springiness, gumminess and shear force values were obtained only at $-60^{\circ} \mathrm{C}$, and the authors concluded that cryogenic freezing at $-60{ }^{\circ} \mathrm{C}$ is appropriate for long-term storage of large yellow croaker.

Therefore, it is necessary to be aware of the changes that have occurred, when stored under freezing, as well as the alternatives to prevent or delay lipid oxidation, avoiding losses in its nutritional quality.

Given the above, the objective of this work was to study the effect of herbal salt as a natural antioxidant on the lipid profile and nutritional value of fish (Coryphaena hippurus Linnaeus, 1758) roasted and stored under freezing, at different time intervals.

\section{Materials and methods}

\subsection{Food material}

Six samples of Dolphinfish (Coryphaena hippurus (Linnaeus, 1758), each weighing around $1500 \mathrm{~g}$, were acquired just after fishing, in the period from September to November 2018, coming from the sea coast of Alagoas, Brazil, between the geographical coordinates $8^{\circ} 8^{\prime} 12^{\prime \prime} \mathrm{S}$ and $10^{\circ} 29^{\prime} 12^{\prime \prime} \mathrm{S}$, where the water reaches a temperature greater than $20^{\circ} \mathrm{C}$ and presents high and constant salinity (Correia \& Sovierzoski, 2005). The samples were placed in plastic bags, kept in polystyrene with ice and immediately taken to the laboratory. The herbs used for cooking (oregano, rosemary and basil) were purchased from a health food store in Maceió, Alagoas, Brazil. The herbal salt was prepared according to the recommendation of the Guide to Good Practices of the Brazilian National Health Surveillance Agency - ANVISA (Brasil, 2014), which consisted of a mixture of basil, oregano, rosemary and refined salt in the proportion of $25 \%$ each.

\section{Food preparation}

Each fish sample (1500 g) was divided into three rectangular portions of $500 \mathrm{~g}$. Groups I and II portions of in natura Dolphinfish were treated with $2.5 \mathrm{~g}$ of refined salt, and group III was treated with $2.5 \mathrm{~g}$ of herbal salt. Group II and III samples were roasted in an oven (dry heat), without adding fat, for 35 minutes at $220^{\circ} \mathrm{C}$. The conditions of preparation were standardized through preliminary tests, based on the sensory characteristics of the food. After cooking, samples from groups I, II and III were crushed, and aliquots were weighed and identified for chemical analysis, referring to "zero time", while the remaining samples, from the three groups, were packed in aseptic plastics, identified and stored in a freezer at $-17 \pm 1{ }^{\circ} \mathrm{C}$, until the time-interval established for analysis (45 or 90 days).

\subsection{Chemical analysis}

The following determinations were made in triplicate:

\section{Centesimal composition and total chloride of the Dolphinfish preparations}

The moisture, protein, ash and total chloride contents were determined using the methodologies of the Manual of the Association of Official Analytical Chemists (1997). Total lipid was extracted by Folch et al. (1957) and the lipid content was gravimetrically determined. The caloric value was calculated from the caloric coefficients corresponding to the proteins and lipids (Livesey, 1990).

\section{Determination of total phenolic compounds in herbs and herbal salt}

The samples of oregano, basil and rosemary were macerated, according to Elfalleh et al. (2012) and homogenized at $80 \%$ methanol, at a ratio of $1: 10(\mathrm{~m}: \mathrm{v})$. The total phenolic contents were measured by spectrophotometry, according to Singleton et al. (1999), modified by Meda et al. (2005). The obtained dry extract was diluted in $80 \%$ methanol, obtaining a concentration of $2000 \mu \mathrm{g} / \mathrm{mL}$, homogenized with $250 \mu \mathrm{L}$ of the Folin-Ciocalteau reagent, $2 \mathrm{~mL}$ of $7.5 \%$ calcium carbonate and $6 \mathrm{~mL}$ of distilled water and allowed to stand, at room temperature for 2 hours. The absorbance was measured at $750 \mathrm{~nm}$ and the results were expressed as gallic acid equivalent (mg gallic acid/100 g sample extract).

\section{Fatty acid profile of the Dolphinfish preparations}

Aliquots of lipid extracts obtained according to Folch et al. (1957) were converted to methyl esters (Hartman \& Lago, 1973) and injected into a SP-2560 fused silica chromatographic column (biscynopropyl polysiloxane) with $100 \mathrm{~m}$ in length and $0.25 \mathrm{~mm}$ in diameter, of a gas chromatograph (GC) (Chromatograph GC Shimadzu ${ }^{\circledast} 2010$-plus/software SP-2560 GC solution). The column temperature programming was isothermal at $140{ }^{\circ} \mathrm{C}$ for $5 \mathrm{~min}$ 
and then heating at $4{ }^{\circ} \mathrm{C} / \mathrm{min}$ to $240{ }^{\circ} \mathrm{C}$, remaining at this for $20 \mathrm{~min}$. The vaporizer temperature was $250^{\circ} \mathrm{C}$ and the detector temperature was $260^{\circ} \mathrm{C}$, using Helium $(1 \mathrm{~mL} / \mathrm{min})$ as gas carrier. The sample split ratio was $1 / 50$. The retention time of methyl esters of the samples was compared with the retention time of standard fatty acid methyl esters. The quantification of the fatty acids was done by normalizing the area, expressing the result in $\mathrm{mg} / 100 \mathrm{~g}$.

\section{Nutritional quality indexes of the lipids of the Dolphinfish preparations}

The nutritional quality of the lipid fraction was evaluated according to the fatty acid composition, using the following three indexes: atherogenic index (AI), the thrombogenic index (TI) (Ulbricht \& Southgate, 1991) and the hypocholesterolemic to hypercholesterolemic fatty acid ratio (H/H) (Santos-Silva et al., 2002). The AI corresponds to the ratio between the sum of saturated fatty acids with 12, 14 and 16 carbons, as pro-atherogenic by the sum of $\mathrm{n} 3$ and $\mathrm{n} 6$ polyunsaturated fatty acids, oleic acid and other monounsaturated acids as anti-atherogenic (Ulbricht \& Southgate, 1991). On the other hand, the TI correlates the ratio between the sum of saturated fatty acids, with 14,16 and 18 carbons by the sum of $n 3$ and n 6 polyunsaturated fatty acids, oleic acid and other monounsaturated acids (Ulbricht \& Southgate, 1991). The $\mathrm{H} / \mathrm{H}$ ratio is related more specifically to the fatty acids that have relation with cholesterol metabolism, this is the relation between the sum of 18:1n9, 18:2n6, 20:4n6, 18:3n3, 20:5n3 and $22: 6 \mathrm{n} 3$ with the sum of $14: 0$ and 16:0 (Santos-Silva et al., 2002).

\subsection{Statistical analysis}

It was planned a completely randomized experimental design with three treatments (in natura Dolphinfish, roasted Dolphinfish treated with herbal salt or roasted Dolphinfish with refined salt). Data were subjected to analysis of variance (ANOVA), with a significance level of 5\%, with subsequent performance of the Tukey parametric test when necessary. Tabulation and data analysis were performed using SPSS ${ }^{\circledR}$ Statistics software, version 17.

\section{Results and discussion}

The results of the centesimal composition, chlorides and caloric value of the studied samples (Dolphinfish in natura, roasted with herbal salt and roasted with refined salt), at time zero and after 45 and 90 days of storage under freezing), are shown in Table 1.

Table 1. Centesimal composition (g/100 g), chloride content (g/100 g) and caloric value (kcal/100 g) of in natura Dolphinfish, roasted with herbal salt and roasted with refined salt, and freezing under different time-intervals ( 0,45 and 90 days).

\begin{tabular}{|c|c|c|c|c|}
\hline \multirow{2}{*}{ Analytes * } & \multirow{2}{*}{ Groups } & \multicolumn{3}{|c|}{ Storage Time (days) } \\
\hline & & 0 & 45 & 90 \\
\hline \multirow[t]{2}{*}{ Moisture } & In natura & $80.32^{\mathrm{Aa}}( \pm 0.14)$ & $77.95^{\mathrm{Aa}}( \pm 0.33)$ & $73.00^{\mathrm{Aa}}( \pm 0.29)$ \\
\hline & RHS & $65.67^{\mathrm{Ab}}( \pm 1.38)$ & $71.36^{\mathrm{Aa}}( \pm 1.03)$ & $72.47^{\mathrm{Aa}}( \pm 0.54)$ \\
\hline \multirow[t]{2}{*}{ Proteins } & In natura & $12.11^{\mathrm{Aa}}( \pm 1.43)$ & $13.97^{\mathrm{Aa}}( \pm 0.25)$ & $13.55^{\mathrm{Aa}}( \pm 1.24$ \\
\hline & RHS & $25.46^{\mathrm{Ab}}( \pm 0.81)$ & $23.50^{\mathrm{Ab}}( \pm 0.84)$ & $24.41^{\mathrm{Ab}}( \pm 0.71)$ \\
\hline \multirow[t]{3}{*}{ Ashes } & In natura & $1.25^{\mathrm{Aa}}( \pm 0.07)$ & $1.11^{\mathrm{Aa}}( \pm 0.02)$ & $1.12^{\text {Аа }}( \pm 0.10)$ \\
\hline & $R S$ & $2.49^{\mathrm{Ab}}( \pm 0.19)$ & $2.27^{\mathrm{Ab}}( \pm 0.03)$ & $2.12^{\mathrm{Ab}}( \pm 0.08)$ \\
\hline & RHS & $1.99^{\mathrm{Aa}}( \pm 0.04)$ & $1.86^{\mathrm{Aa}}( \pm 0.03)$ & $1.84^{\mathrm{Aa}}( \pm 0.05)$ \\
\hline \multirow[t]{3}{*}{ Chlorides } & In natura & $1.45^{\mathrm{Aa}}( \pm 0.12)$ & $1.45^{\mathrm{Aa}}( \pm 0.11)$ & $1.45^{\mathrm{Aa}}( \pm 0.11)$ \\
\hline & $R S$ & $3.62^{\mathrm{Ab}}( \pm 0.16)$ & $3.75^{\mathrm{Ab}}( \pm 0.18)$ & $3.71^{\mathrm{Ab}}( \pm 0.12)$ \\
\hline & RHS & $2.90^{\mathrm{Aa}}( \pm 0.13)$ & $2.90^{\mathrm{Aa}}( \pm 0.21)$ & $2.91^{\mathrm{Aa}}( \pm 0.1)$ \\
\hline \multirow[t]{3}{*}{ Carbohydrates } & In natura & $4.09^{\mathrm{Aa}}( \pm 1.32)$ & $4.04^{\mathrm{Aa}}( \pm 0.21)$ & $9.16^{\mathrm{Aa}}( \pm 1.37)$ \\
\hline & RS & $1.15^{\mathrm{Aa}}( \pm 0.22)$ & - & $3.60^{\mathrm{Aa}}( \pm 3.44)$ \\
\hline & RHS & $5.09^{\mathrm{Aa}}( \pm 1.50)$ & $2.44^{\mathrm{Aa}}( \pm 0.76)$ & $2.34^{\mathrm{Aa}}( \pm 0.76)$ \\
\hline Calories & In natura & $84.83^{\mathrm{Aa}}( \pm 2.15)$ & $98.44^{\mathrm{Aa}}( \pm 1.62)$ & $119.2^{\mathrm{Aa}}( \pm 1.2)$ \\
\hline \multirow[t]{2}{*}{$\mathrm{kcal} / 100 \mathrm{~g}$} & $R S$ & $120.85^{\mathrm{Aa}}( \pm 4.42)$ & $115.1^{\mathrm{Aa}}( \pm 1.56)$ & $141.3^{\mathrm{Aa}}( \pm 1.01)$ \\
\hline & RHS & $138.26^{\mathrm{Aa}}( \pm 3.25)$ & $124.1^{\mathrm{Aa}}( \pm 7.11)$ & $116.9^{\mathrm{Aa}}( \pm 2.41)$ \\
\hline
\end{tabular}

${ }^{*}$ Mean \pm standard deviation, in parentheses, of samples analyzed, in triplicate; Different capital letters on the same line and different lower letters in the same column indicate a significant difference of $5 \%$ probability, according to the Tukey test. RS: Roasted with salt; RHS: Roasted with herbal salt. 
A significant reduction $(\mathrm{p}<0.05)$ was detected in the moisture content of the Dolphinfish after roasting it with herbal salt and roasting with refined salt, at time "zero". Lira et al. (2020) detected similar results in a study with roasted fish. The baking technique is a type of cooking by dry heat at temperatures ranging between $180^{\circ} \mathrm{C}$ and $230^{\circ} \mathrm{C}$ (Araújo et al., 2011). This culinary method reduces the moisture content, through the loss of water, and concentrates the dry matter of the food.

During storage under freezing, there were reductions in moisture content, although not significant $(\mathrm{p}<0.05)$. Carneiro et al. (2000), also detected a reduction in the moisture content in marinated sardine fillet, subjected to freezing $\left(2.5^{\circ} \mathrm{C}\right)$ for 2 months and Pires et al. (2002), reported a reduction in humidity and an increase in the concentration of other chemical components on pork loin, subjected to freezing, at different temperatures, for 15 and 60 days.

The protein content of the samples roasted with herbal salt and roasted with refined salt showed significant increases ( $\mathrm{p}<0.05)$, in relation to the fresh samples, at time "zero" and after 45 and 90 days of storage under freezing. Such findings can be associated with water loss and dry matter concentration by the furnishing process. As the consumption of 150 grams of fish is enough to satisfy 50 to $60 \%$ of the protein requirements/day of an adult (Food and Agricultural Organization of the United Nations, 2014), the results obtained indicate that the Dolphinfish, in the two established treatments, can be considered a good protein source of high biological value.

According to the classification of Penfield \& Campbell (1990), the Dolphinfish can be considered a lean fish, since it has a lipid content below $5 \%$.

The percentage of chlorides in the roasted Dolphinfish with refined salt showed a significant increase $(p>0.05)$, compared to fresh Dolphinfish or to the roasted Dolphinfish with herbal salt, at time "zero" and during storage under freezing, due to the higher salt content used in this preparation.

\subsection{Phenolic compounds}

Table 2 shows the levels of total phenolic compounds detected in rosemary, oregano, basil and herbal salt.

Table 2. Total phenolic compounds (mg gallic acid/100 g sample extract) of the herbs and herbal salt studied and stored under freezing.

\begin{tabular}{lccc}
\hline \multirow{2}{*}{ Samples $^{*}$} & \multicolumn{2}{c}{ Total Phenols (in different days of freezing) } \\
\cline { 2 - 4 } & 0 & 45 & 90 \\
\hline Rosemary & $103.98( \pm 4.9)^{\mathrm{aA}}$ & $128.61( \pm 3.9)^{\mathrm{aB}}$ & $145.41( \pm 4.8)^{\mathrm{aC}}$ \\
Oregano & $147.25( \pm 4.7)^{\mathrm{bA}}$ & $171.11( \pm 5.0)^{\mathrm{bB}}$ & $191.29( \pm 5.1)^{\mathrm{bC}}$ \\
Basil & $112.51( \pm 7.6)^{\mathrm{aA}}$ & $137.89( \pm 4.6)^{\mathrm{aB}}$ & $158.22( \pm 4.5)^{\mathrm{aC}}$ \\
Herbal salt & $149.99( \pm 8.0)^{\mathrm{bA}}$ & $192.46( \pm 8.1)^{\mathrm{cB}}$ & $236.87( \pm 8.9)^{\mathrm{cC}}$ \\
\hline
\end{tabular}

${ }^{*}$ Mean \pm standard deviation, in parentheses, of samples analyzed, in triplicate; Different capital letters on the same line and different lower letters in the same column indicate a significant difference of $5 \%$ probability, according to the Tukey test.
Oregano had a higher content of total phenolic compounds and a significant difference $(\mathrm{p}<0.05)$, compared to rosemary and basil. Several beneficial health effects are associated with phenolic compounds present in fruits, vegetables, teas and wines, such as antioxidant, anti-inflammatory, antimicrobial and anticarcinogenic activities (Alarcón-Flores et al., 2013). Such effects are mainly due to the reducing properties and their chemical structure, which act by neutralizing or sequestering free radicals, acting in the initiation stage and in the propagation of the oxidative process (Castelo-Branco \& Torres, 2011).

Studies of Lira et al. (2020), using the same herbs, have similar results. Del-Ré \& Jorge (2012) who, among the spices evaluated (oregano, basil and thyme), concluded that oregano had one of the highest levels of total phenolic compounds, also found that it had the highest antioxidant activity. Lee \& Scagel (2009) had shown before that oregano and basil have high antioxidant potential in studies with the application of these spices in various products susceptible to oxidation, and according to Bonanni et al. (2008), basil has a high antioxidant capacity. Bhale et al. (2007) mentioned previously that the levels of phenolic compounds, responsible for the antioxidative function of oregano and rosemary, are quite similar. Montero et al. (2005), used the rosemary extract to protect against lipid oxidation in fish ground and subjected to thermal treatments (conventional and microwave) and detected that this herb was able to maintain its antioxidant capacity, as measured by the reduction of the DPPH radical. Rosemary also showed high antioxidant potential, in studies using products with high susceptibility to oxidation, especially lipids, in research conducted by Bhale et al. (2007) and Lee et al. (2005).

Alezandro et al., (2011) had found before that, among the oregano, basil and rosemary, the former had greater antioxidant action.

The pharmacologically active compounds of oregano, rosemary and basil have already been described as phenolics, flavonoids, terpenes or essential oils, being considered functional foods (Mendes et al., 2015). Oregano has been highlighted, for instance, for their antimicrobial properties, which can inhibit the development of microorganisms, especially pathogens, in addition to antioxidant capacity (Martins et al., 2010).

Lira et al. (2020), detected the profile of the main phenolic compounds present in rosemary, basil, oregano, and the mixture of such herbs and the herbal salt, used to prepare fish food. The authors identified coumaric acid, salicylic acid and rutin in rosemary, basil and oregano. Rutin was the phenolic more prevalent in all the studied groups, but rosemary showed the highest concentration $(587.041 \mathrm{mg} / \mathrm{L})$. Salicylic acid showed higher concentrations in oregano $(36.649 \mathrm{mg} / \mathrm{L})$, while quercetin was detected (low concentrations) only in rosemary and basil, being the last one the only herb in which caffeic, coumaric and vanillic acids, as well as coumarin and kaempferol were also detected, although its concentrations of salicylic acid, rutin and quercetin were significantly lower $(\mathrm{p}<0.05)$ than in the other herbs/groups.

Rutin, being one of the most potent flavonoids in terms of preventing oxidative damage, has a more expressive antilipoperoxidant role, with a consequent increase in HDL-cholesterol and reduction 
of risk factors for atherosclerosis and cardiovascular diseases (Metodiewa et al., 1997; Rodrigues et al., 2003).

In the present study, it was detected that storage under freezing promoted an increase in the levels of phenolic compounds in all herbs, with significant differences $(\mathrm{p}<0.05)$, between storage times. Lira et al. (2019), detected a significant increase $(p>0.05)$ of $11.7 \%$, in the concentration of total white onion phenols, after 90 days of storage under freezing, in relation to zero time. Araújo et al. (2009) in a study with blackberry, observed a slight increase in phenolic contents until the ninth day of storage under freezing, followed by a gradual reduction in the storage process.

\subsection{Fatty acid profile}

The fatty acid profiles of the samples of Dolphinfish (in natura or roasted pre-treated with refined salt or with herbal salt and submitted to freezing) are shown in Table 3. The fatty acids of greater predominance detected in the fresh Dolphinfish coincided with the ones detected in the other samples. Nineteen fatty acids were separated, identified and quantified, beng six of them saturated, five monounsaturated and eight polyunsaturated. The most prevalent saturates were: palmitic, stearic and pentadecyl. Among the monounsaturated, the common was oleic acid, and among the polyunsaturated, docosahexaenoic (DHA), arachidonic

Table 3. Fatty acid profile (mg/100 g) of fresh golden filet, roasted with herbal salt and roasted with refined salt.

\begin{tabular}{|c|c|c|c|c|c|c|c|c|c|}
\hline \multirow{2}{*}{ FÁTTY ACIDS ${ }^{*}$} & \multicolumn{3}{|c|}{ Time 0} & \multicolumn{3}{|c|}{45 days } & \multicolumn{3}{|c|}{90 days } \\
\hline & In natura & Herbal salts & Salt & In natura & Herbal salts & Salt & In natura & Herbal salts & Salt \\
\hline Mirístic (C14:0) & $13.23( \pm 4.17)^{\mathrm{aA}}$ & $9.04( \pm 2.89)^{\text {aA }}$ & $8.76( \pm 0.61)^{\mathrm{bA}}$ & $19.44( \pm 3.13)^{\mathrm{aA}}$ & $17.36( \pm 1.31)^{\mathrm{aB}}$ & $6.99( \pm 0.87)^{\mathrm{bB}}$ & $22.83( \pm 1.01)^{a A}$ & $23.71( \pm 2.03)^{\mathrm{aB}}$ & $6.02( \pm 2.40)^{\mathrm{bB}}$ \\
\hline $\begin{array}{l}\text { Pentadecanoic } \\
(\mathrm{C} 15: 0)\end{array}$ & $160.34( \pm 57.44)^{\mathrm{aA}}$ & $174.95( \pm 28.0)^{\mathrm{aA}}$ & $148.83( \pm 71.92)^{\mathrm{bA}}$ & $308.77( \pm 47.53)^{\mathrm{aA}}$ & $206.0( \pm 17.01)^{\mathrm{bA}}$ & $180.0( \pm 42.7)^{\mathrm{cB}}$ & $601.0( \pm 97.81)^{\text {aA }}$ & $414.66( \pm 77.4)^{\text {aA }}$ & $262.33\left( \pm 51.23^{\mathrm{bB}}\right.$ \\
\hline Palmitic (C16: 0) & $314.04( \pm 91.99)^{\mathrm{aA}}$ & $259.15( \pm 45.3)^{\mathrm{aA}}$ & $244.05( \pm 69.94)^{\mathrm{bA}}$ & $459.91( \pm 25.42)^{\mathrm{aA}}$ & $388.54( \pm 19.3)^{\mathrm{aB}}$ & $288.9( \pm 31.7)^{\mathrm{bA}}$ & $528.16( \pm 68.9)^{\mathrm{aA}}$ & $468.8( \pm 52.89)^{\mathrm{aB}}$ & $439.33\left( \pm 17.61^{\mathrm{bB}}\right.$ \\
\hline $\begin{array}{l}\text { Heptadecanoic } \\
(\mathrm{C} 17: 0)\end{array}$ & $15.02( \pm 4.94)^{\mathrm{aA}}$ & $13.62( \pm 3.76)^{\mathrm{aA}}$ & $10.66( \pm 4.06)^{\mathrm{bA}}$ & $16.46( \pm 0.07)^{\mathrm{aA}}$ & $14.60( \pm 1.18)^{\mathrm{aA}}$ & $10.11( \pm 0.48)^{\mathrm{bA}}$ & $18.23( \pm 2.71)^{\text {aA }}$ & $16.02( \pm 3.72)^{a A}$ & $11.02( \pm 0.32)^{\mathrm{bA}}$ \\
\hline Stearic (C18: 0) & $234.41( \pm 78.27)^{\mathrm{aA}}$ & $187.05( \pm 35.8)^{\mathrm{aA}}$ & $170.58( \pm 51.36)^{\mathrm{bA}}$ & $335.98( \pm 2.99)^{\text {aA }}$ & $275.26( \pm 11.6)^{\mathrm{bB}}$ & $197.0( \pm 19.3)^{\mathrm{CA}}$ & $447.11( \pm 21.1)^{\mathrm{aA}}$ & $349.9( \pm 44.01)^{\mathrm{aB}}$ & $210.31\left( \pm 11.23^{\mathrm{bA}}\right.$ \\
\hline Araquic (C20: 0) & $3.07( \pm 0.74)^{\mathrm{aA}}$ & $1.61( \pm 0.40)^{\mathrm{aA}}$ & $1.93( \pm 0.73)^{\mathrm{bA}}$ & $1.86( \pm 1.19)^{\mathrm{aA}}$ & $1.92( \pm 0.10)^{\mathrm{aA}}$ & $1.61( \pm 0.14)^{\mathrm{aA}}$ & $1.12( \pm 0.09)^{\mathrm{aA}}$ & $2.29( \pm 0.82)^{\text {aA }}$ & $1.43( \pm 0.31)^{\mathrm{bA}}$ \\
\hline $\begin{array}{l}\text { Palmitoleic } \\
\text { (C16: } 1 \omega-7)\end{array}$ & $21.49( \pm 6.80)^{\mathrm{aA}}$ & $15.82( \pm 3.76)^{\mathrm{aA}}$ & $13.62( \pm 2.93)^{\mathrm{bA}}$ & $30.10( \pm 1.22)^{\mathrm{aA}}$ & $26.21( \pm 1.35)^{\mathrm{aB}}$ & $18.94( \pm 2.04)^{\mathrm{bB}}$ & $39.06( \pm 7.01)^{\mathrm{aA}}$ & $34.51( \pm 4.44)^{\mathrm{aB}}$ & $23.01( \pm 0.98)^{\mathrm{bB}}$ \\
\hline $\begin{array}{l}\text { Cis-10Heptadecanoic } \\
\text { (C 17: 1) }\end{array}$ & $5.48( \pm 1.96)^{\mathrm{aA}}$ & $5.02( \pm 1.36)^{\mathrm{aA}}$ & $4.77( \pm 1.28)^{\mathrm{bA}}$ & $13.32( \pm 8.47)^{\mathrm{aA}}$ & $6.60( \pm 0.39)^{\mathrm{bA}}$ & $4.77( \pm 1.43)^{\mathrm{bB}}$ & $19.44( \pm 2.31)^{\mathrm{aA}}$ & $7.08( \pm 1.27)^{\mathrm{aA}}$ & $5.12( \pm 0.02)^{\mathrm{bB}}$ \\
\hline Oleic (C18: $1 \omega-9)$ & $196.20( \pm 48.16)^{\mathrm{aA}}$ & $174.18( \pm 32.8)^{\mathrm{aA}}$ & $157.24( \pm 30.4)^{\mathrm{bA}}$ & $300.75( \pm 30.54)^{\mathrm{aA}}$ & $285.60( \pm 12.7)^{\mathrm{aB}}$ & $177.6( \pm 15.9)^{\mathrm{bA}}$ & $400.31( \pm 19.0)^{\mathrm{aA}}$ & $362.0( \pm 14.33)^{\mathrm{aB}}$ & $201.04\left( \pm 11.35^{\text {bB }}\right.$ \\
\hline Gadoleic (C20: $1 \omega 11)$ & $5.97( \pm 1.64)^{\mathrm{aA}}$ & $3.42( \pm 0.80)^{\mathrm{aA}}$ & $3.05( \pm 0.51)^{\mathrm{bA}}$ & $7.00( \pm 1.64)^{\mathrm{aA}}$ & $4.51( \pm 0.16)^{\mathrm{bA}}$ & $3.46( \pm 0.03)^{\mathrm{bB}}$ & $7.98( \pm 0.02)^{\mathrm{aA}}$ & $5.71( \pm 0.13)^{\mathrm{aA}}$ & $4.10( \pm 0.52)^{\mathrm{bB}}$ \\
\hline Nervonic (C24: 1) & $7.18( \pm 2.12)^{\mathrm{aA}}$ & $3.82( \pm 0.60)^{\text {aA }}$ & $4.19( \pm 1.42)^{\mathrm{bA}}$ & $3.40( \pm 1.35)^{\mathrm{aA}}$ & $4.15( \pm 0.17)^{\mathrm{aA}}$ & - & $1.36( \pm 0.11)^{\text {aA }}$ & $5.98( \pm 1.11)^{\text {aA }}$ & $3.76( \pm 0.54)^{\mathrm{bB}}$ \\
\hline Linoleic (C18: $2 \omega-6)$ & $25.35( \pm 1.64)^{\text {aA }}$ & $18.65( \pm 6.01)^{\mathrm{aA}}$ & $16.00( \pm 3.42)^{\mathrm{bA}}$ & $34.39( \pm 16.50)^{\mathrm{aA}}$ & $26.37( \pm 4.18)^{\mathrm{aA}}$ & $16.72( \pm 1.09)^{\mathrm{bB}}$ & $41.65( \pm 3.76)^{a A}$ & $34.23( \pm 4.88)^{\mathrm{aB}}$ & $17.55( \pm 3.24)^{\mathrm{bB}}$ \\
\hline $\begin{array}{l}\text { Linolenic (C 18: } \\
3 \omega-3)\end{array}$ & $6.95( \pm 2.15)^{\mathrm{aA}}$ & $5.53( \pm 0.60)^{\mathrm{aA}}$ & $3.33( \pm 5.91)^{\mathrm{bA}}$ & $5.13( \pm 4.29)^{\mathrm{aA}}$ & $4.62( \pm 0.10)^{\mathrm{aB}}$ & $1.92( \pm 0.85)^{\mathrm{bB}}$ & $4.88( \pm 1.93)^{\mathrm{aA}}$ & $1.22( \pm 0.02)^{\mathrm{aA}}$ & $2.03( \pm 0.81)^{\mathrm{bB}}$ \\
\hline $\begin{array}{l}\text { Eicosadienoic } \\
(\mathrm{C} 20: 2 \omega-6)\end{array}$ & $8.77( \pm 2.55)^{\mathrm{aA}}$ & $6.80( \pm 1.44)^{\mathrm{aA}}$ & $3.52( \pm 0.79)^{\mathrm{bA}}$ & $10.85( \pm 0.00)^{\mathrm{aA}}$ & $7.74( \pm 0.10)^{\mathrm{bA}}$ & $4.52( \pm 0.10)^{\mathrm{bB}}$ & $13.14( \pm 0.09)^{\mathrm{aA}}$ & $6.49( \pm 0.04)^{\mathrm{aA}}$ & $6.07( \pm 0.01)^{\mathrm{bB}}$ \\
\hline $\begin{array}{l}\text { Arachidonic } \\
\text { (C20: } 4 \omega-6)\end{array}$ & $112.5( \pm 38.95)^{\mathrm{aA}}$ & $104.11( \pm 19.97)^{\mathrm{Aa}}$ & $83.24( \pm 23.57)^{\mathrm{bA}}$ & $147.18( \pm 24.4)^{\mathrm{aA}}$ & $128.62( \pm 2.28)^{\mathrm{aA}}$ & $105.7( \pm 11.5)^{\mathrm{aB}}$ & $176.02( \pm 32.1)^{\mathrm{aA}}$ & $161.0( \pm 33.56)^{\mathrm{aB}}$ & $113.82( \pm 6.01)^{\mathrm{bB}}$ \\
\hline $\begin{array}{l}\text { Eicosapentaenoic } \\
\text { (EPA) (C20: } 5 \omega-3)\end{array}$ & $55.71( \pm 19.55)^{\mathrm{aA}}$ & $48.36( \pm 9.06)^{\text {aA }}$ & $40.26( \pm 11.63)^{\mathrm{bA}}$ & $67.77( \pm 15.04)^{\mathrm{aA}}$ & $60.78( \pm 0.12)^{\mathrm{aA}}$ & $50.02( \pm 7.15)^{\mathrm{bB}}$ & $73.22( \pm 12.02)^{\mathrm{aA}}$ & $75.66( \pm 8.23)^{a B}$ & $62.02( \pm 7.02)^{\mathrm{bB}}$ \\
\hline $\begin{array}{l}\text { Docosapentaenoic } \\
\text { (DPA) (C22: } 5 \omega-3)\end{array}$ & $24.50( \pm 8.07)^{\mathrm{aA}}$ & $16.62( \pm 3.26)^{\mathrm{aA}}$ & $13.89( \pm 4.26)^{\mathrm{bA}}$ & $25.94( \pm 3.47)^{\mathrm{aA}}$ & $19.59( \pm 0.34)^{\mathrm{aA}}$ & $17.47( \pm 0.98)^{\mathrm{aB}}$ & $27.37( \pm 7.33)^{\text {aA }}$ & $24.11( \pm 6.01)^{\mathrm{aA}}$ & $22.14( \pm 3.00)^{\mathrm{bB}}$ \\
\hline $\begin{array}{l}\text { Docosahexaenoic } \\
\text { (DHA) }(\mathrm{C} 22: 6 \omega-3)\end{array}$ & $636.37( \pm 232.6)^{\mathrm{aA}}$ & $589.37( \pm 116.4)^{\mathrm{Aa}}$ & $472.0( \pm 155.34)^{\mathrm{bA}}$ & $821.03( \pm 138.9)^{2 A}$ & $697.69( \pm 6.83)^{\mathrm{bA}}$ & $571.5( \pm 70.6)^{\mathrm{CB}}$ & $993.99( \pm 55.72)^{\mathrm{aA}}$ & $754.84( \pm 41.12)^{\mathrm{aB}}$ & $691.04( \pm 90.1)^{\mathrm{bB}}$ \\
\hline Elaidic (C18: $1 \omega-9 \mathrm{t})$ & $6.21( \pm 1.94)^{\mathrm{aA}}$ & $4.63( \pm 0.84)^{\mathrm{aA}}$ & $3.94( \pm 1.38)^{\mathrm{bA}}$ & $5.88( \pm 2.09)^{\mathrm{aA}}$ & $5.89( \pm 1.48)^{\mathrm{aA}}$ & $4.30( \pm 0.13)^{\mathrm{aA}}$ & $5.42( \pm 1.22)^{\mathrm{aA}}$ & $6.17( \pm 1.00)^{\mathrm{aA}}$ & $4.77( \pm 0.81)^{\mathrm{bA}}$ \\
\hline Not identified & $56.13( \pm 19.76)$ & $41.16( \pm 9.80)$ & $41.52( \pm 14.72)$ & $90.42( \pm 28.07)$ & $64.14( \pm 9.06)$ & $88.19( \pm 19.81)$ & $133.10( \pm 2.31)$ & $152.44( \pm 25.00)$ & $132.91( \pm 14.21)$ \\
\hline$\Sigma$ Saturated & $750.56( \pm 246.74)$ & $651.55( \pm 118.72)$ & $591.15( \pm 202.69)$ & $1142.46( \pm 80.33)$ & $903.74( \pm 50.61)$ & $828.8( \pm 165.01)$ & $1618.46( \pm 43.23)$ & $1123.16( \pm 99.4)$ & $1082.77( \pm 87.3)$ \\
\hline$\Sigma$ Saturated & $1195.3( \pm 376.5)$ & $972.99( \pm 191.24)$ & $832.12( \pm 247.27)$ & $1480.61( \pm 239.97)$ & $1022.26( \pm 26.10)$ & $978.0( \pm 119.23)$ & $1798.42( \pm 91.88)$ & $1472.87( \pm 18.9)$ & $1200.7( \pm 65.07)$ \\
\hline ¿Polyinsaturated & $928.73( \pm 305.63)$ & $768.60( \pm 150.79)$ & $635.93( \pm 206.93)$ & $1112.3( \pm 202.69)$ & $942.71( \pm 14.28)$ & $755.70( \pm 91.48)$ & $1330.27( \pm 46.76)$ & $1057.56( \pm 22.4)$ & $963.67( \pm 71.06)$ \\
\hline$\Sigma$ Monounsaturated & $266.59( \pm 70.95)$ & $204.40( \pm 40.45)$ & $196.20( \pm 40.34)$ & $368.32( \pm 37.27)$ & $300.07( \pm 14.77)$ & $222.34( \pm 27.75)$ & $468.15( \pm 23.71)$ & $415.31( \pm 23.34)$ & $237.03( \pm 52.71)$ \\
\hline PUFA/AGS & $1.23( \pm 0.33)$ & $1.17( \pm 0.52)$ & $1.07( \pm 0.81)$ & $0.97( \pm 0.54)$ & $1.04( \pm 0.81)$ & $0.91( \pm 0.67)$ & $0.82( \pm 0.01)$ & $0.94( \pm 0.23)$ & $0.89( \pm 0.09)$ \\
\hline$\sum \omega-3$ & $782.11( \pm 262.5)$ & $657.68( \pm 129.4)$ & $533.17( \pm 179.14)$ & $919.88( \pm 161.73)$ & $779.98( \pm 7.73)$ & $643.68( \pm 79.64)$ & $1099.46( \pm 73.29)$ & $855.83( \pm 54.67)$ & $826.23( \pm 91.13)$ \\
\hline$\Sigma \omega-6$ & $226.24( \pm 69.22)$ & $170.93( \pm 33.49)$ & $157.56( \pm 45.74)$ & $290.96( \pm 52.36)$ & $241.48( \pm 7.80)$ & $179.48( \pm 21.54)$ & $230.81( \pm 49.11)$ & $201.73( \pm 38.35)$ & $137.44( \pm 28.71)$ \\
\hline$\Omega-6 / \omega-3$ ratio & $1: 3.45( \pm 0.57)$ & $1: 3.84( \pm 0.43)$ & $1: 3.38( \pm 0.74)$ & $1: 3.16( \pm 0.91)$ & $1: 3.22( \pm 0.68)$ & $1: 3.58( \pm 0.34)$ & $1: 4.76( \pm 0.81)$ & $1: 4.24( \pm 0.09)$ & $1: 6.01( \pm 0.92)$ \\
\hline $\begin{array}{l}\mathrm{EPA}+\mathrm{DHA} \\
(\mathrm{mg} / 100 \mathrm{~g})\end{array}$ & $752.08( \pm 252.26)$ & $512.33( \pm 166.97)$ & $637.73( \pm 125.52)$ & $888.81( \pm 153.98)$ & $621.59( \pm 77.81)$ & $758.47( \pm 6.96)$ & $1067.21( \pm 8.72)$ & $830.50( \pm 16.42)$ & $802.06( \pm 28.45)$ \\
\hline
\end{tabular}

${ }^{*}$ Averages of six samples in duplicate, with standard deviation. Superscripts a, b indicate differences in treatments and superscripts A, B indicate differences between the analyzed timeintervals of freezing. Lines and columns with different superscripts differ significantly $(\mathrm{p}<0.05)$ according to the Tukey test at $5 \%$ probability. 
and eicosapentaenoic (EPA) stood out. These results were similar to the ones obtained by Sancho et al. (2011), with white hake cooked with 5\% coriander, used as a natural antioxidant.

At time "zero", the fatty acid content of the fresh samples did not show a statistically significant difference $(\mathrm{p}>0.05)$ from that in the samples of roasted fish pre-treated with herbal salt, although values statistically lower $(p>0.05)$ were detected in the roasted samples pre-treated with refined salt, with a significant reduction $(\mathrm{p}>0.05)$ in the levels of stearic $(8.8 \%)$, oleic acid (9.68\%), DHA (19.9\%), arachidonic acid (20.04\%) and EPA (16.7\%).

Cooking can cause rupture of cell membranes by promoting lipid oxidation. This allows polyunsaturated fatty acids and cholesterol from food to come into contact, or them suffer interaction with molecules that have pro-oxidant activities (alkoxyl and hydroxyl radicals), propagating the oxidation and increasing the amount of free radicals (Aliño et al., 2009; Costa et al., 2011). The results obtained in the present study show that, due to the presence of phenolic compounds and their antioxidant activity, which are not degraded during the heat treatment, the spices contained in the herbal salt have a positive effect in the inhibition of the lipid oxidation of the roasted Dolphinfish, when compared to the pre-treated with refined salt (Table 3). The use of refined salt in greater quantity, on the other hand, may have intensified the lipid oxidation reaction, due to its pro-oxidant action (Bertolin et al., 2011; Belitz et al., 2012; Mariutti \& Bragagnolo 2017), influencing the degradation of monounsaturated and polyunsaturated fatty acids in the roasted fish. These results are compatible with the findings of Lira et al. (2020), in which it was detected that bioactive substances from herbs had an antioxidant action on the fatty acid profile in roasted fish.

The use of natural antioxidants is an important measure to mitigate lipid oxidation in foods, due to its ability to sequester or prevent the formation of free radicals, in addition to the advantage of its use being indicated as a safe way, from the point of view of the health of the consumer, compared to the use of synthetics, which can cause probable harm to health (Kulawik et al., 2012; Mercadante et al., 2010). Dietary antioxidants also play an important role in the human body's defensive system, protecting against oxidative damage to cells and tissues. The evidence strongly suggests a contribution of polyphenols to the prevention of various chronic diseases and can generate health benefits, in the immune system, prevention of heart disease and cancer (Hathwar et al., 2011; Haugaard et al., 2014).

At 45 and 90 days of storage under freezing, a behavior similar to time "zero" was observed, and values statistically lower ( $p>0.05)$ were detected in the samples roasted with salt, in relation to those that were roasted with herbal salt, except for docosapentaenoic fatty acid in samples stored for 45 days under freezing. After 45 and 90 days, the following losses in the fatty acid profile were, respectively, observed: $28.4 \%$ and $39.8 \%$ in the stearic; $37.9 \%$ and $44.4 \%$ in oleic; $18 \%$ and $8.4 \%$ in DHA; $17.8 \%$ and $29.3 \%$ in arachidonic; $17.7 \%$ and $18.0 \%$ in EPA.

After 45 days of storage, a significant reduction $(\mathrm{p}<0.05)$ in the total monounsaturated fatty acids $(25.9 \%)$ and in the total polyunsaturated fatty acids (19.8\%) was detected in the roasted Dolphinfish pre-treated with refined salt, in comparison to the roasted fish pre-treated with herbal salt. After 90 days, the significant losses $(\mathrm{p}<0.05)$ corresponded to: $42.9 \%$ in the total of monounsaturated fatty acids and $8.88 \%$ in the total of polyunsaturated fatty acids.

These results point out that the introduction of spices contained in herbal salt in everyday food preparations can have benefits, since, from the health point of view, a high concentration of polyunsaturated fatty acids is desirable and one of the relevant points of the nutritional value of fish is related to their presence. Even after heat treatment and 90 days of storage under freezing, fish prepared with herbal salt and roasted represents an important source of monounsaturated and polyunsaturated fatty acids, which have not been degraded, due to the antioxidant capacity of the phenolic compounds present in herbs, which can be considered a functional food.

The Brazilian Society of Cardiology (SBC), through the Brazilian Dyslipidemia and Atherosclerosis Prevention Directive (Faludi et al., 2017) recommends 0.5-1 g/day of omega 3 (EPA, DHA and linolenic acid) for individuals with normal levels of triacyl glycerides (150-199 mg/dL), 1-2 g/day for individuals with high levels of triacyl glycerides (200-499 mg/dL), and 2-4 g for individuals with very high levels of triacyl glycerides ( $\geq 500 \mathrm{mg} / \mathrm{dL}$ ). $\mathrm{SBC}$ also recommends, as a preventive measure, that healthy normal individuals consume a variety of fishes (preferably oily) and the daily intake of $1 \mathrm{~g}$ of omega 3 (EPA, DHA and linolenic acid) for patients with coronary disease (Faludi et al., 2017). The seabream baked with herbal salt showed $643.26 \mathrm{mg} / 100 \mathrm{~g}$ at zero time, $763.09 \mathrm{mg} / 100 \mathrm{~g}$, at 45 days and $831.72 \mathrm{mg} / 100 \mathrm{~g}$ at 90 days, and thus, it is able to supply the daily needs for the individuals with normal levels of triacyl glycerides.

The English National Health Service (1994) describes that a AGPI/AGS ratio $<0.45$ constitutes an unhealthy diet, due to its potential to allow an increase in blood cholesterol. The AGPI/AGS ration found in the fresh samples studied in this work as well as in the roasted samples stored under freezing (Table 3 ) were all in accordance with the recommendation.

According to Uauy et al. (1999), the Japan Society for Lipid Nutrition recommends that the $\omega-6 / \omega-3$ ratio be $4: 1$ for healthy adults and the World Health Organization (2005) recommends $\omega-6 / \omega-3$ ratios between 1:3 and 1:4. The proper relationship between $n-6$ and $n-3$ is necessary to avoid an imbalance in the synthesis of eicosanoids, with the risk of promoting a deficiency of n-3 (Merdzhanova et al., 2012). The $n-6 / n-3$ ratio also influences the development of obesity and cardiovascular diseases (Vaz et al., 2014). Therefore, in this perspective, Dolphinfish, regardless of the treatments mentioned above, can be considered beneficial for the health of those who consume it.

\subsection{Nutritional quality indexes (IQN) of lipids}

The nutritional quality of the lipid profile of the fish samples studied was evaluated by three indexes regarding fatty acid profile, and the results are described in Table 4. 
Table 4. Nutritional quality indexes of the lipid fraction of roasted Dolphinfish, previously treated with herbal salt or with refined common iodized salt.

\begin{tabular}{lccc}
\hline \multicolumn{1}{c}{ Dolphinfish } & $\mathrm{AI}^{*}$ & $\mathrm{TI}^{*}$ & $\mathrm{H} / \mathrm{H}^{*}$ \\
\hline In natura & $0.41( \pm 0.66)^{\mathrm{a}}$ & $0.31( \pm 0.50)^{\mathrm{a}}$ & $1.71( \pm 0.80)^{\mathrm{b}}$ \\
Roasted with herbal salt & $0.40( \pm 0.03)^{\mathrm{a}}$ & $0.37( \pm 0.30)^{\mathrm{a}}$ & $1.41( \pm 0.90)^{\mathrm{a}}$ \\
Roasted with refined salt & $0.55( \pm 0.03)^{\mathrm{a}}$ & $0.34( \pm 0.14)^{\mathrm{a}}$ & $1.46( \pm 1.09)^{\mathrm{a}}$ \\
\hline
\end{tabular}

Averages of six samples in duplicate, with standard deviation. ${ }^{*} \mathrm{TI}=$ thrombogenicity index; $\mathrm{AI}=$ atherogenicity index and $\mathrm{H} / \mathrm{H}=$ ratio of hypocholesterolemic and hypercholesterolemic. Equal letters in the same column do not differ statistically at the level of $5 \%$ of probability according to the Tukey test.

The atherogenicity index (IA) and the thrombogenicity index (IT) reflect the different effects that fatty acids influence on the occurrence of the increased appearance of atheroma and/or thrombus. Despite not having an established parameter for such indexes, the lower are their values, the greater are the amount of anti-atherogenic fatty acids present in the food, reflecting on the greater potential for preventing the emergence of coronary diseases (Garaffo et al., 2011).

The results of the atherogenicity factor in samples of fresh and roasted Dolphinfish pre-treated with refined or herbal salt, were respectively $0.41,0.40$ and 0.55 , and the ones of thrombogenicity factor were, respectively, $0.31,0.37$ and 0.34 . These results indicated that all the samples of Dolphinfish had a great potential to prevent the onset of coronary diseases (Garaffo et al., 2011).

The $\mathrm{H} / \mathrm{H}$ ratio indicates the cholesterolemic potential regarding the cholesterol metabolism, being desired that the particular food has high values for such a relationship (Campo et al., 2013). In the present study, the $\mathrm{H} / \mathrm{H}$ index was $1.71,1.41$ and 1.46 respectively in the in natura and roasted with refined salt or with herbal salt Dolphinfish. There is a reduction in this index after the cooking process, due to losses of fatty acids during heat treatment.

\section{Conclusions}

The most prevalent fatty acids that were detected in the Dolphinfish at time "zero" coincided in all the established treatments (in natura, roasted with herbal salt and roasted with refined salt), and were DHA (n-3), palmitic and stearic (saturated), oleic (n-9), arachidonic (n-6), pentadecyl (saturated) and EPA (n-3).

The percentage of chlorides in roasted Dolphinfish pre-treated with refined salt was significantly higher $(p>0.05)$ when compared to in natura or roasted but pre-treated with herbal salt, at time "zero" and during the storage under freezing. Oregano had a higher content of phenolic compounds ( $p>0.05)$ compared to rosemary and basil.

The fatty acid content of the fresh samples at time "zero", 45 and 90 days of storage under freezing, did not show any significant difference ( $p>0.05)$, in comparison to the roasted sea salt with herbs, which showed higher values $(p>0.05)$ in relation to roast with salt, indicating that the spices contained in the herbal salt inhibited lipid oxidation, due to the presence of phenolic compounds, rich in natural antioxidants, providing a positive effect on the consumer's health, preserving the quality of the food.
Roasted Dolphinfish pre-treated with herbal salt can be considered a functional food, a good source of fatty acids beneficial to health, even after heat treatment and 90 days of freezing storage. At time "zero" and after 45 and 90 days of storage under freezing, the nutritional quality indexes of fresh golden lipids, roasted after treatment with herbal salt or with common refined salt were favorable to the consumer health, as well as the proportion of PUFA/AGS and the $\omega-6 / \omega-3$ ratio.

\section{References}

Alarcón-Flores, M. I., Romero-González, R., Vidal, J. L. M., \& Frenich, A. G. (2013). Multiclass determination of phytochemicals in vegetables and fruits by ultra high performance liquid chromatography coupled to tandem mass spectrometry. Food Chemistry, 141(2), 1120-1129. http://dx.doi.org/10.1016/j.foodchem.2013.03.100. PMid:23790894.

Alencar, T. O. S., Bastos, V. P., Alencar, B. R., \& Freitas, I. V. (2011). Dispensação farmacêutica: uma análise dos conceitos legais em relação à prática profissional. Revista de Ciências Farmacêuticas Básica e Aplicada, 32(1), 89-94.

Alezandro, M. R., Lui, M. C. Y., Lajolo, F. M., \& Genovese, M. I. (2011). Commercial spices and industrial ingredients: evaluation of antioxidant capacity and flavonoids content for functional foods development. Food Science and Technology, 31(2), 527-533. http:// dx.doi.org/10.1590/S0101-20612011000200038.

Aliño, M., Grau, R., Toldrá, F., Blesa, E., Pagán, M. J., \& Barat, J. M. (2009). Influence of sodium replacement on physicochemical properties of dry-cured loin. Meat Science, 83(3), 423-430. http:// dx.doi.org/10.1016/j.meatsci.2009.06.022. PMid:20416693.

Ansorena, D., Barriuso, B., Cardenia, V., Astiasarán, I., Lercker, G., \& Rodriguez-Estrada, M. T. (2013). Thermo-oxidation of cholesterol: effect of the unsaturation degree of the lipid matrix. Food Chemistry, 141(3), 2757-2764. http://dx.doi.org/10.1016/j. foodchem.2013.04.129. PMid:23871021.

Araújo, P., Rodrigues, R., Machado, A., Santos, V., \& Silva, J. (2009). Influência do congelamento sobre as características físico-químicas e o potencial antioxidante de néctar de amora-preta. Boletim do Centro de Pesquisa e Processamento de Alimentos, 27(2). http:// dx.doi.org/10.5380/cep.v27i2.22029.

Araújo, W. M. C., Botelho, R. B. A., Montebello, N. P., \& Borgo, L. A. (2011). Alquimia dos alimentos (Vol. 2). Brasília: SENAC.

Association of Official Analytical Chemists - AOAC. (1997). Official methods of analysis (16th ed., Vol. 2, No. 32). Gaitherburg: AOAC International.

Badiani, A., Stipa, S., Bitossi, F., Gatta, P. P., Vignola, G., \& Chizzolini, R. (2002). Lipid composition, retention and oxidation in fresh and completely trimmed beef muscles as affected by commom culinary practices. Meat Science, 60(2), 169-186. http://dx.doi.org/10.1016/ S0309-1740(01)00119-X. PMid:22063241. 
Belitz, H.D., Grosch, W. \& Shieberle, P. (2012). Química de los alimentos. Zaragoza: Acribia.

Bertolin, T. E., Guarienti, C., Farias, D., Souza, F. T., Gutkoski, L. C., \& Colla, L. M. (2011). Efeito antioxidante da ficocianina em pescado salgado-seco. Ciência Agrotécnica, 35(4), 751-757. http:// dx.doi.org/10.1590/S1413-70542011000400014.

Bhale, S. D., Xu, Z., Prinyawiwatkul, W., King, J. M., \& Godber, J. S. (2007). Oregano and rosemary extracts inhibit oxidation of longchain n-3 fatty acids in menhaden oil. Journal of Food Science, 72(9), C504-C508. http://dx.doi.org/10.1111/j.1750-3841.2007.00569.x. PMid:18034711.

Bocchi, E. A., Marcondes-Braga, F. G., Bacal, F., Ferraz, A. S., Albuquerque, D., \& Rodrigues, D. (2012). Atualização da diretriz brasileira de insuficiência cardíaca crônica - 2012. Arquivos Brasileiros de Cardiologia, 98(1), 1-33. http://dx.doi.org/10.1590/S0066-782X2012001000001.

Bonanni, P. S., Cortina, M., \& Campas, M. (2008). Electrochemical biosensors as a tool for antioxidant capacity assessment. Food Chemistry, 102, 751-758.

Braga, A. A. D., \& Barleta, V. C. N. (2007). Alimento funcional: uma abordagem nova abordagem terapêutica das dislipidemias como prevenção de doenças aterosclerótica. Cadernos UniFOA, 2(3), 1-28.

Brasil, Ministério da Saúde, Secretaria de Atenção à Saúde, Departamento de Atenção Básica. (2014). Guia alimentar para a população brasileira (2. ed.). Brasília: Ministério da Saúde.

Campo, M. M., Santaliestra-Pasías, A. M., Sañudo, C., Muela, E., Olleta, J. L., Moreno, L. A., \& Mesana, M. I. (2013). Influence of cooking method on the nutrient composition of Spanish light lamb. Journal of Food Composition and Analysis, 31(2), 185-190. http://dx.doi. org/10.1016/j.jfca.2013.05.010.

Carneiro, M. J. M., Tobinaga, S., Cristianini, M., Goli, T., \& RaoultWack, A. L. (2000). Influência do método de congelamento em filé de sardinha marinado. Revista Brasileira de Produtos Agroindustriais, 2(1), 1-6. http://dx.doi.org/10.15871/15178595/rbpa.v2n1p1-6.

Castelo-Branco, V. N., \& Torres, A. G. (2011). Capacidade antioxidante total de óleos vegetais comestíveis: determinantes químicos e sua relação com a qualidade dos óleos. Revista de Nutrição, 24(1), 173187. http://dx.doi.org/10.1590/S1415-52732011000100017.

Cornejo, F. E. P., Nogueira, R. I., \& Park, K. J. (1999). Manual para produção de pescado salgado-seco (Vol. 39, pp. 1-20). Rio de Janeiro: Embrapa.

Correia, M D. \& Sovierzoski, H.H. (2005). Ecossistemas marinhos: recifes, praias e manguezais (Conversando sobre Ciências em Alagoas). Maceió: EDUFAL.

Costa, R. G., Medeiros, G. R., Duarte, T. F., Pedrosa, N. A., Voltolini, T. V., \& Madruga, M. S. (2011). Salted goat and lamb meat: typical regional product of the city of Petrolina, state of Pernambuco. Small Ruminant Research, 98(1-3), 51-54. http://dx.doi.org/10.1016/j. smallrumres.2011.03.017.

Del Ré, P. V., \& Jorge, N. (2012). Especiarias como antioxidantes naturais: aplicações em alimentos e implicação na saúde. Revista Brasileira de Plantas Medicinais, 14(2), 389-399. http://dx.doi.org/10.1590/ S1516-05722012000200021.

Elfalleh, W., Hannachi, H., Tlili, N., Yahia, Y., Nasri, N., \& Ferchichi, A. (2012). Total phenolic contents and antioxidant activities of pomegranate peel, seed, leaf and flower. Journal of Medicinal Plants Research, 6(32), 4724-4730. http://dx.doi.org/10.5897/JMPR11.995.

Elosta, A., Ghous, T., \& Ahmed, N. (2012). Produtos naturais como agentes anti-glicação: possível potencial terapêutico para complicações diabéticas. Current Diabetes Reviews, 8(2), 92-108. http://dx.doi. org/10.2174/157339912799424528. PMid:22268395.

Faludi, A. A., Izar, M. C. O., Saraiva, J. F. K., Chacra, A. P. M., Bianco, H. T., Afiune, N., Abrahão, B., Adriana, P., Alexandre, C., Lottenberg, A. M., Sposito, A. C., Chagas, A. C. P., Casella, F., Antonio, S., Antônio, F., Alencar, F., Aristóteles, C., Caramelli, B., Magalhães, C. C., Negrão, C. E., Ferreira, C. E. S., Scherr, C., Feio, C. M. A., Kovacs, C., Araújo, D. B., Magnoni, D., Calderaro, D., Gualandro, D. M., Mello, E. P. Jr., Alexandre, E. R. G., Sato, E. I., Moriguchi, E. H., Rached, F. H., Santos, F. C., Cesena, F. H. Y., Fonseca, F. A. H., Fonseca, H. A. R., Xavier, H. T., Mota, I. C. P., Giuliano, I. C. B., Issa, J. S. D., Jayme, P. J. B., Santos, J. E., Faria, J. R. No., Melo, J. X. Fo., Kato, J. T., Torres, K. P., Bertolami, M. C., Assad, M. H. V., Miname, M. H., Scartezini, M., Forti, N. A., Coelho, O. R., Maranhão, R. C., Santos, R. D. Fo., Alves, R. J., Cassani, R. L., Betti, R. T. B., Carvalho, T., Martinez, T. M. R., Giraldez, V. Z. R., \& Salgado, W. Fo. (2017). Atualização da Diretriz Brasileira de Dislipidemias e Prevenção da Aterosclerose - 2017. Arquivos Brasileiros de Cardiologia, 109(2, Suppl. 1), 1-76. http://dx.doi. org/10.5935/abc.20170121.

Farsi, P. F., Djazayery, A., Eshraghian, M. R., Koohdani, F., Saboor-Yaraghi, A. A., Derakhshanian, H., Zarei, M., Javanbakht, M. H., \& Djalali, M. (2014). Effects of supplementation with omega-3 on insulin sensitivity and non-esterified free fatty acid (NEFA) in type 2 diabetic patients. Arquivos Brasileiros de Endocrinologia \& Metabologia, 58(4), 335-340. http://dx.doi.org/10.1590/0004-2730000002861. PMid:24936727.

Folch, J., Lees, M., \& Stanley, G. H. A. S. (1957). Simple method for the isolation and purification of total lipids from animal tissues. The Journal of Biological Chemistry, 226(1), 497-509. PMid:13428781.

Food and Agricultural Organization of the United Nations - FAO. (2014). The state of world fisheries and aquaculture. Rome: FAO.

Food and Agricultural Organization of the United Nations - FAO. (2016). El estado mundial de la pesca y la acuicultura: contribución a la seguridad alimentaria y la nutrición para todos. Rome: FAO.

Garaffo, M. A., Vassallo-Agius, R., Nengas, Y., Lembo, E., Rando, R., Maisano, R., Dugo, G., \& Giuffrida, D. (2011). Fatty acids profile, Atherogenic (IA) and Thrombogenic (IT) Health Lipid Indices, of Raw Roe of Blue Fin Tuna 737 (Thunnus thynnus L.) and their salted product "Bottarga". Food and Nutrition Sciences, 02(2), 736-743. http://dx.doi.org/10.4236/fns.2011.27101.

García-Arias, M. T., Álvarez Pontes, E., García-Linares, M. C., GarcíaFernández, M. C., \& Sánchez-Muniz, F. J. (2003). Cooking-freezingreheating (CFR) of sardine (Sardina pilchardus) fillets: effect of different cooking and reheating procedures on the proximate and fatty acid compositions. Food Chemistry, 83(3), 349-356. http:// dx.doi.org/10.1016/S0308-8146(03)00095-5.

Garófolo, A., \& Petrilli, A. S. (2006). Balanço entre ácidos graxos ômega-3 e 6 na resposta inflamatória em pacientes com câncer e caquexia. Revista de Nutrição, 19(5), 611-621. http://dx.doi.org/10.1590/ S1415-52732006000500009.

Ghawi, S. K., Rowland, I., \& Methven, L. (2014). Enhancing consumer liking of low salt tomato soup over repeated exposure by herb and spice seasonings. Appetite, 81, 20-29. http://dx.doi.org/10.1016/j. appet.2014.05.029. PMid:24879887.

Hartman, L., \& Lago, R. C. A. (1973). Rapid preparation of fatty acid methyl esters from lipids. Laboratory Practice, 22(6), 475-476. PMid:4727126.

Hathwar, S. C., Bijinu, B., Rai, A. K., \& Narayan, B. (2011). Simultaneous recovery of lipids and proteins by enzymatic hydrolysis of fish industry waste using different commercial proteases. Applied Biochemistry 
and Biotechnology, 164(1), 115-124. http://dx.doi.org/10.1007/ s12010-010-9119-5. PMid:21057982.

Haugaard, P., Hansen, F., Jensen, M., \& Grunert, K. G. (2014). Consumer atitudes toward new technique for preserving organic meat using herbs and berries. Meat Science, 96(1), 126-135. http://dx.doi. org/10.1016/j.meatsci.2013.06.010. PMid:23896146.

International Life Sciences Institute - ILSI, Comitê de Nutrição, Força-tarefa Alimentos Fortificados e Suplementos. (2009). Funções plenamente reconhecidas de nutrientes: sódio (Série de Publicações ILSI Brasil, No. 4). São Paulo: ILSI Brasil.

Kulawik, P., Özogul, F., Glew, R., \& Özogul, Y. (2012). Significance of antioxidants for seafood safety and human health: a review. Journal of Agricultural and Food Chemistry, 61(3), 475-491. http://dx.doi. org/10.1021/jf304266s.

Lee, J., \& Scagel, C. F. (2009). Chicoric acid found in basil (Ocimum basilicum L.) leaves. Food Chemistry, 115(2), 650-656. http://dx.doi. org/10.1016/j.foodchem.2008.12.075.

Lee, S. J., Umano, K., Shibamoto, T., \& Lee, K. G. (2005). Identification of volatile components in basil (Ocimum basilicum L.) and thyme leaves (Thymus vulgaris L.) and their antioxidant properties. Food Chemistry, 91(1), 131-137. http://dx.doi.org/10.1016/j.foodchem.2004.05.056.

Lira, G. M., Lopez, A. M. Q., Nanes, G. M. F., \& Silva, F. G. C. (2019). Chemical interaction between white onion, as natural antioxidant, on shrimp stored under freezing. Food Science and Technology, 39(Suppl. 2), 535-542. http://dx.doi.org/10.1590/fst.22218.

Lira, G. M., Pinheiro, A. G. A., Monte-Guedes, C. K. R., Lopez, A. M. Q., Mendonça, E. L. S. S., Nanes, G. M. F., Silva, F. G. C., Nascimento, T. G., \& Souza, J. S. (2020). Impact of antioxidant herbal salts on the lipid fraction, acceptability and consumption intent of roasted Dolphinfish. Food Science and Technology. http://dx.doi.org/10.1590/ fst.29219.

Livesey, G. (1990). Valores energéticos de carboidratos e dietas não disponíveis: uma investigação e análise. The American Journal of Clinical Nutrition, 51(4), 617-637. http://dx.doi.org/10.1093/ ajcn/51.4.617. PMid:2138862.

Mariutti, L. R. B., \& Bragagnolo, N. (2017). Influence of salt on lipid oxidation in meat and seafood products: a review. Food Research International, 94, 90-100. http://dx.doi.org/10.1016/j.foodres.2017.02.003. PMid:28290372.

Martins, A. G. L. A., Nascimento, A. R., Mouchrek Filho, J. E., Mendes Filho, N. E., Souza, A. G., Aragão, N. E., \& Silva, D. S. V. (2010). Atividade antibacteriana do óleo essencial do manjericão frente a sorogrupos de Escherichia coli enteropatogênica isolados de alfaces. Ciência Rural, 40(8), 1791-1796. http://dx.doi.org/10.1590/S010384782010005000127.

Meda, A., Lamien, C. E., Romito, M., Millogo, J., \& Nacoulma, O. G. (2005). Determination of the total phenolic, flavonoid and proline contents in Burkina Fasan honey, as well as their radical scavenging activity. Food Chemistry, 91(1), 571-577. http://dx.doi.org/10.1016/j. foodchem.2004.10.006.

Mendes, G. M., Rodrigues-das-Dores, R. G., \& Campideli, L. C. (2015). Avaliação do teor de antioxidantes, flavonoides e compostos fenólicos em preparações condimentares. Revista Brasileira de Plantas Medicinais, 17(2), 297-304. http://dx.doi.org/10.1590/1983-084X/13_069.

Mercadante, A. Z., Capitani, C. D., Decker, E. A., \& Castro, I. A. (2010). Effect of natural pigments on the oxidative stability of sausages stored under refrigeration. Meat Science, 84(4), 718-726. http://dx.doi. org/10.1016/j.meatsci.2009.10.031. PMid:20374848.

Merdzhanova, A., Stancheva, M., \& Makedonski, L. (2012). Fatty acid composition of Bulgarian Black Sea fish species. Analele
Universitatii Ovidius Constanta. Seria Chimie, 23(1), 41-47. http:// dx.doi.org/10.2478/v10310-012-0006-5.

Metodiewa, D., Kochman, A., \& Karolczak, S. (1997). Evidence for antiradical and antioxidant properties of four biologically active N, N-Diethylaminoethyl-ethers 320. Biochemistry and Molecular Biology International, 41, 1067-1075. PMid:9137839.

Montero, P., Giménez, B., Pérez-Mateos, M., \& Gómez-Guillén, M. C. (2005). Oxidation stability of muscle with quercetin and rosemary during thermal and high-pressure gelation. Food Chemistry, Barking, 93(1), 17-23. http://dx.doi.org/10.1016/j.foodchem.2004.08.038.

Moraes, F. P., \& Colla, L. M. (2006). Alimentos funcionais e nutracêuticos: definições, legislação e benefícios à saúde. Revista Eletrônica de Farmácia, 3(2), 109-122.

National Health Service - NHS. (1994). Report on health and social subjects: nutritional aspects of cardiovascular disease. London: HMSO.

Oetterer, M., Savay-da-Silva, L. K. \& Galvão, J. A. (2012). Congelamento éo melhor método para a conservação do pescado (Visão Agrícola, No. 11). Piracicaba: Escola Superior de Agricultura "Luiz de Queiroz", Universidade de São Paulo.

Pardi, M. C., Santos, I. F., Souza, E. R., \& Pardi, H. S. (2001). Ciência, higiene e tecnologia da carne. Goiânia: UFG.

Penfield, M. P., \& Campbell, A. M. (1990). Experimental food science (3rd ed.). San Diego: Academic Press.

Pires, I. S. C., Rosado, G. P., Azeredo, R. M. C., Neves, M. B., \& Miranda, L. S. (2002). Composição centesimal, perdas de peso e maciez de lombo (Longissimus dorsi) suíno submetido a diferentes tratamentos de congelamento e descongelamento. Revista de Nutrição, 15(2), 163-172. http://dx.doi.org/10.1590/S1415-52732002000200005.

Raposo, H. F. (2010). Efeito dos ácidos graxos n-3 e n-6 na expressão de genes do metabolismo de lipídeos e risco de aterosclerose. Revista de Nutrição, 23(5), 871-879. http://dx.doi.org/10.1590/ S1415-52732010000500017.

Rodrigues, H. G., Diniz, Y. S.-A., Faine, L. A., Almeida, J. A., Fernandes, A. A. H., \& Novelli, E. L. B. (2003). Suplementação nutricional com antioxidantes naturais: efeito da rutina na concentração de colesterol-HDL. Revista de Nutrição, 16(3), 315-320. http://dx.doi. org/10.1590/S1415-52732003000300009.

Saldanha, T., \& Bragagnolo, N. (2010). Effects of grilling on cholesterol oxide formation and fatty acids alterations in fish. Food Science and Technology, 30(2), 385-390. http://dx.doi.org/10.1590/S010120612010000200015.

Sancho, R. A. S., Lima, F. A., Costa, G. G., Mariutti, L. R. B., \& Bragagnolo, N. (2011). Effect of annatto seed and coriander leaves as natural antioxidants in fish meatballs during frozen storage. Journal of Food Science, 76(6), C838-C845. http://dx.doi.org/10.1111/j.17503841.2011.02224.x. PMid:22417481.

Santos-Silva, J., Bessa, R. J. B., \& Santos-Silva, F. (2002). Effect of genotype, feeding system and slaughter weight on the quality of light lambs: II. Fatty acid composition of meat. Livestock Production Science, 77(2-3), 187-194. http://dx.doi.org/10.1016/S0301-6226(02)00059-3.

Sartori, A. G. O., \& Amâncio, R. D. (2012). Pescado: importância nutricional e consumo no Brasil. Segurança Alimentar e Nutricional, 19(2), 83-93. http://dx.doi.org/10.20396/san.v19i2.8634613.

Singleton, V. L., Orthofer, R., \& Lamuelaraventós, R. M. (1999). Analysis of total phenols and other oxidation substrates and antioxidants by means of Folin-Ciocateau reagent. Methods in Enzymology, San Diego, 299, 152-178. http://dx.doi.org/10.1016/S0076-6879(99)99017-1.

Truonghuynh, H. T., Li, B., Zhu, H., Guo, Q., \& Li, S. (2020). Freezing methods affect the characteristics of large yellow croaker (Pseudosciaena 
crocea): use of cryogenic freezing for long-term storage. Food Science and Technology. http://dx.doi.org/10.1590/fst.27719.

Uauy, R., Mena, P., \& Valenzuela, A. (1999). Essencial fatty acids as determinants of lipids requirements in infants, children and adults. European Journal of Clinical Nutrition, 53(1), 66-77. http://dx.doi. org/10.1038/sj.ejcn.1600745.

Ulbricht, T. L. V., \& Southgate, D. A. T. (1991). Coronary heart disease: seven dietary factors. Lancet, 338(8773), 985-992. http://dx.doi. org/10.1016/0140-6736(91)91846-M. PMid:1681350.

Vaz, D. S. S., Guerra, F. M. R. M., Gomes, C. F., Simão, A. N. C., \& Martins, J. Jr. (2014). A importância do ômega 3 para a saúde humana: um estudo de revisão. Revista Uningá Review, 20(2), 48-54.
Verdi, R., Gasparino, E., Coradini, M. F., Chambo, A. P. S., Feihrmann, A. C., Goes, E. S. R., \& Souza, M. L. R. (2020). Inclusion of dehydrated mix of tilapia and salmon in pizzas. Food Science and Technology. http://dx.doi.org/10.1590/fst.22019.

World Health Organization - WHO. (2005). Nutrition in adolescence: issues and challenges for the health sector: issues in adolescent health and development. Geneva: WHO Regional Office for Europe.

Zemdegs, J. C. S., Pimentel, G. D., \& Priel, M. B. (2009). Ácidos graxos ômega-3 e tratamento da esquizofrenia. Revista de Psiquiatría Clínica, 37(5), 223-227. http://dx.doi.org/10.1590/ S0101-60832010000500007. 